\title{
A Brief Summary of Teacher Recruitment and Retention in the Smallest
}

\author{
Illinois Rural Schools
}

\author{
John David Ulferts \\ Western Illinois University
}

Teacher recruitment and retention factors were identified in the smallest public school districts in Illinois. Findings were compared to a previous study of Montana rural teacher recruitment and retention conducted by Davis (2002). A quantitative survey instrument was administered to teachers employed in the 24 smallest Illinois school districts. The survey consisted of Likert-type items measuring recruitment, retention, and job satisfaction factors and was based on the Boylan (1993) four spheres of influence for teacher recruitment and retention: 1) within classroom activities, 2) whole school level activities, 3) community level activities, and 4) family/personal factors. Results were similar to the Davis study with the family/personal and whole school level spheres most important to teacher recruitment and the community and within classroom spheres most important to teacher retention. Teachers were also asked to identify the recruitment and retention strategies they perceived as being most important for rural school districts and to respond to three professional satisfaction questions. The study concluded with recommendations for both educational practitioners and researchers.

Keywords: recruitment, retention, teacher satisfaction, smallest rural school districts

\section{Introduction}

A highly effective teacher, according to a growing consensus of educational researchers, is the single most important school-related determinant to student achievement (The Southeast Center for Teacher Quality, 2004). According to Huysman (2008), "the most valuable and accessible resources located within a rural school district are the teaching staff' (p. 31). Rural schools have a clear interest in their most valuable resource: their teaching staff. Not only do rural schools need to attract highly qualified teachers, rural schools must also ensure effective teachers are retained. Research has also demonstrated teacher job satisfaction, highly correlated with teacher retention, has positive implications for both student achievement and school quality (Huysman, 2008). If the factors contributing to rural teacher job satisfaction can be identified, recruitment efforts may attract better qualified teachers and reduce teacher attrition, resulting in increased student achievement and economic savings for rural districts.

Teacher attrition is a significant concern nationwide. However, rural schools are particularly affected by attrition. Roughly one-third of U.S. teachers exit the profession within the first three years of teaching and nearly half do so after five years (Ingersoll, 2001). Despite the high cost of an undergraduate degree, Riggs (2013) reported $9.5 \%$ of all beginning teachers quit before the end of their first year teaching. Furthermore, nearly $16 \%$ of all teachers leave their assignments every year resulting in a teacher turnover rate four times higher than other professions (Riggs, 2013). It is not uncommon for rural schools in Alaska, for example, to have teacher turnover rates as high as $40 \%$ annually (Dessoff, 2010). Rural schools of less than 300 students have the highest rate of teacher turnover (Ingersoll, 2001). High teacher attrition, so prevalent in rural schools, negatively impacts student achievement and growth forcing students to repeatedly have novice teachers who are often in the survival mode (Huling, 1998). The National Commission on Teaching and America's Future (2007) warned of the effects of high teacher turnover on rural schools causing them to be "... frequently staffed with inequitable concentrations of under-prepared, inexperienced teachers who are left to labor on their own to meet the needs of their students" (p. 2). Inexperienced teachers like the ones found all too-often in rural schools "... are less effective than those with some experience under their belts" (Rice \& the Urban Institute, 2010, p. 1). The impact of experience is greater at the elementary and middle levels than at the high school, and is strongest in the subject of math (Rice \& the Urban Institute).

Teacher recruitment efforts and retention woes add to the economic distress of rural schools.

Because rural districts have to invest time and money into professional development of new staff, “.... a high turnover rate of teachers affects the financial 
efficiency of a district as well as student achievement" (Eberhard, Reinhardt-Mondragon, \& Stottlemyer, 2000, p. 4). It is not surprising, therefore, that rural superintendents cite recruitment and retention of highly qualified staff as their number one concern (Natkin, 2003). Rural districts have a particularly difficult time attracting and retaining secondary science and math teachers with $16 \%$ of rural districts having No Child Left Behind compliance issues with science teachers and $10 \%$ having NCLB compliance issues with math teachers (Zhang, 2008). The inability of rural schools to attract teacher candidates "... leaves principals in the precarious position of having to hire whoever walks through the door, or failing to offer some courses" (Maranto \& Shuls, 2012, p. 32). Kim and Loadman (1994) suggested that if administrators better understood the job satisfaction of their teachers "...then there may be an opportunity to intervene in those cases where job satisfaction is marginal or low, or where it is high, this may be a way to maintain it at a high level" (p. 10).

The challenges of rural school recruitment and retention have a detrimental impact on student achievement resulting in rural schools "hiring underprepared teachers, more out-of-field teaching assignments, larger classes, fewer advanced course options, less coordinated curriculum, less experienced teaching staff, and fragmented professional development" (Jimerson, 2003, p. 13). As rural administrators watch yet another teacher walk out the schoolhouse door, rocker Jackson Browne's plea to his audience in the final track from the album Running on Empty may well come to mind: "Oh, won't you stay, just a little bit longer? Please, please, please, Say you will, say you will" (Williams, 1960). Rural schools, and especially rural students, cannot afford running their classrooms on empty because of the negative effects on students and student achievement. But if rural schools are to entice their teachers to stay a little bit longer, then rural educational leaders need to develop a better understanding of the recruitment and retention factors that influence teachers to accept and remain teaching in the smallest school districts in Illinois.

Once rural leaders understand the perceived strategies that rural teachers consider to be most important in the recruitment and retention of teachers, rural leaders can positively influence teacher recruitment and retention, reduce professional development costs, and increase student achievement. Understanding recruitment and retention factors can help other rural schools nurture their most valuable resource, their teaching staff, and reduce the negative cost of teacher attrition in lost professional development and student achievement opportunities.
Because most rural school districts have limited resources, quality teachers matter as much, if not more, to rural school districts than to larger suburban or urban school districts.

To determine whether the Davis (2002)

Montana findings could be generalized to rural schools in other states, and whether the findings were still relevant more than a decade later, the following three questions guided this study:

1. What recruitment factors most influence teachers to accept teaching assignments in the smallest public school districts in Illinois?

2. What retention factors most influence teachers to remain teaching in the smallest school districts in Illinois?

3. What perceived strategies would rural teachers suggest to improve teacher recruitment and increase teacher retention in the smallest public school districts in Illinois?

If rural leaders understand the factors that contribute to teachers choosing to teach and remain teaching in rural areas, then rural districts can improve their teacher recruitment and retention, as well as reduce the costs associated with additional professional development of new staff, and accelerate student achievement.

\section{Background of Study}

In the first major study of its kind, Boylan et al. (1993) examined teacher satisfaction and retention in rural school districts of New South Wales, Australia. In the two year study, Boylan et al. surveyed 1,100 teachers. The findings of Boylan et al. led to the development of a rural teacher retention model which was based on four spheres of influence: 1) within classroom, 2) whole school, 3) community, and 4) family/personal factors.

Nearly a decade later, Davis (2002) sought out Boylan's assistance in the development of a quantitative survey measuring teacher recruitment, retention, and job satisfaction factors. The Davis survey also asked rural teachers to identify those strategies they perceived as effective for encouraging teachers to select and remain teaching in small rural Montana school districts. The Davis study focused on 147 teachers in the 107 smallest Montana schools. All of the schools in the Davis (2002) study had enrollments of less than 100 students with $71 \%$ of the participating districts employing just one teacher. Davis found that rural teacher recruitment was most strongly influence by factors associated with the family/personal sphere while teacher retention was most strongly influenced by the community sphere. 
Despite her recommendation that "similar size elementary school districts in other states...be identified and a similar study conducted to determine whether findings from this study are comparable to teacher populations in other rural states," until now no researcher has replicated the Davis study to test whether its findings remain relevant and are transferable beyond Montana's borders. While replication is necessary to validate scientific research, Makel and Plucker (2014) found just 0.13 percent of educational research reported in the top 100 education journals has ever been replicated.

\section{Methodology}

To determine whether the Davis (2002) findings could be generalized to rural schools in other states, and whether the findings were still relevant more than a decade later, replication of the Davis study was needed. Thus, the present study sought to provide external validity to the Davis study by identifying the recruitment and retention factors most influential to teachers in the smallest school districts in Illinois and the sphere of influence groups to which the factors belonged. The Davis survey instrument was used with permission to collect the perceptions of Illinois rural teachers to determine whether the Montana study results could be replicated and to answer the research questions. All 24 of the Illinois school districts in the study had enrollments of less than 100 students qualifying them as rural by the U.S. Department of Education (less than 600 students) and were located in communities of less than 2500 residents meeting the U.S. Census Bureau definition of rural. The survey instrument was previously tested for reliability and validity by having a team of experts check question construct and field tested in Montana schools.

The study used a quantitative descriptive approach with a mixed mode survey collection method incorporating both an electronic and a paper survey of rural teachers. The survey consisted of questions of Likert-type items measuring factors associated with Boylan et al.'s (1993) four spheres of influence which affect the recruitment, retention, and job satisfaction of rural teachers. Factors from the Boylan et al. four spheres of influence (1) within classroom activities, 2) whole school level activities, 3) community level activities and 4) family/personal factors) are thought to affect whether a teacher chooses to remain teaching in a rural district and impacts teacher satisfaction and commitment. Davis (2002) used 27 recruitment and retention factors assigned to the Boylan four spheres of influence to guide the question content of the survey instrument. The following categories of questions were included in the survey instrument: what factors influenced the teacher's decision to accept a position in their present district; what influenced teachers to remain teaching in small rural schools; what additional steps do teachers suggest small rural schools take to recruit and retain teachers; satisfaction with teaching; and, finally, the background of the survey participants. A reliability analysis utilizing Cronbach's Alpha of the Davis (2002) survey instrument after field testing resulted in an alpha score of .88 , indicating a high level of internal consistency between the 27 influence factors. Because the Davis (2002) survey instrument had demonstrated reliability and validity, and measured the study's guiding research questions, the original instrument was not modified in any way for the present Illinois study.

Teacher satisfaction was measured by the survey instrument because high levels of teacher satisfaction have been closely associated with teacher retention. Bogler (2002) and Huysman (2008) both reported teachers who experience high job satisfaction are more likely to remain in the profession and perform as effective teachers. To measure teacher satisfaction, three questions taken from the National Center for Education Statistics School and Staffing Survey (NCES) were included in this study. The NCES Schools and Staffing Survey (SASS) is the largest continual survey of U.S. public schools and has been administered seven times between 1988 and 2012 .

Data collection occurred from October 15, 2014 to December 15, 2014. Two written and four electronic email invitations were sent out to 210 rural teachers in the 24 smallest Illinois school districts stating the potential benefits and risks associated with the study, guaranteeing confidentiality, anonymity of responses, and requesting respondents to either complete the electronic or paper survey but not both. While SurveyMonkey ensured respondents only completed the electronic survey once, there was no way to prevent a respondent from completing both the electronic and the paper survey other than reminding them not to do so. SurveyMonkey was used as a host for data collection for both the electronic and paper surveys with paper surveys entered manually by the researcher and analyzed for descriptive statistics using SPSS statistical software.

\section{Results}

A total of 113 rural teachers responded to the survey representing $54 \%$ of the 210 teachers employed in the 24 smallest Illinois school districts. The majority of respondents $(83.2 \%)$ chose to participate via the printed copy of the survey mailing in their responses. Once all of the survey responses 
were gathered, Cronbach's alpha was used to measure the internal reliability of the survey instrument. A high internal consistency reliability coefficient of .808 was found when the 28 recruitment and retention factors were tested together.

Demographic data for the population sample revealed a largely homogenous group that was $85 \%$ female, $99 \%$ Caucasian, and $76 \%$ married. The majority of respondents (89\%) were elementary or middle school teachers. Respondents reflected all age groups with the largest age groupings from 30 to 39 with $33 \%$ followed by the 50 to 59 grouping with $26 \%$. Nearly all teacher respondents $(89 \%)$ were employed full time. The majority of respondents were either quite new to the rural districts they taught at $27 \%$ had been teaching in their districts for less than three years) or could be considered veteran teachers with $26 \%$ having been employed in their rural districts for 16 or more years. Nearly threefourths of the participants, or $71 \%$, had spent less than three years teaching in districts other than where they were presently employed. Nearly half of the participants had an advanced degree with $44 \%$ holding a Master's and four percent holding an Educational Specialist degree.

The majority of teacher respondents had a rural background growing up $(69.72 \%)$, but were not native to the communities they now taught in $(82.30 \%)$ as shown in Table 1. Furthermore, the majority of respondents did not presently live in the districts where they taught $(83.19 \%)$. If given the opportunity to reside in the districts where they taught, $60 \%$ of teachers reported they would choose not to do so.

Table 1

Profile of the Rural Background of Teacher Respondents

\begin{tabular}{lcc} 
Characteristic & $\underline{\mathrm{n}}$ & $\underline{\text { Percentage }}$ \\
Background of participants growing up & 76 & $69.72 \%$ \\
$\quad$ Rural & 25 & $22.94 \%$ \\
$\quad$ Suburban & $8.34 \%$ \\
$\quad$ Urban & 20 & $17.70 \%$ \\
Participants who grew up in the community now teaching in & 93 & $82.30 \%$ \\
$\quad$ Native to community now teaching in & 19 & $16.81 \%$ \\
$\quad$ Did not grow up in community now teaching in & 94 & $83.19 \%$ \\
Participants who reside in the district where they teach & 45 & $40.18 \%$ \\
$\quad$ Reside within district & 67 & $59.82 \%$ \\
$\quad$ Reside elsewhere & & $7.8 \%$ \\
Would choose to reside in district now teaching in if possible & & \\
Would not choose to reside in district now teaching if possible & & \\
\hline
\end{tabular}

\section{Research Question One Results}

Teachers were asked what recruitment factors most influenced their decision to accept teaching assignments in the smallest Illinois public school districts. "Best or only job offer," "enjoy the rural lifestyle," "family and or home is close by" and "small class size" had the highest means ratings of the recruitment factors that most influenced teachers to accept teaching assignments in the smallest, rural school districts. The means and standard deviations for each of the 12 recruitment factors are listed in Table 2 .

Table 2

Influential Recruitment Factors

\begin{tabular}{lccccc}
\hline Recruitment Factors & $\underline{\mathrm{N}}$ & $\underline{\mathrm{Min}}$ & $\underline{\mathrm{Max}}$ & $\underline{\mathrm{M}}$ & $\underline{\mathrm{SD}}$ \\
Best or only job offer & 111 & 0 & 4 & 4.71 & 1.282 \\
Enjoy the rural lifestyle & 113 & 0 & 4 & 2.655 & 1.280 \\
Family and/or home is close & 112 & 0 & 4.607 & 1.429 \\
by & 112 & 0 & 4 & 2.446 & 1.184 \\
Small class sizes & 113 & 0 & 2.381 & 1.365 \\
Good reputation of the & & & & 4
\end{tabular}

school 


\begin{tabular}{|c|c|c|c|c|c|}
\hline $\begin{array}{l}\text { Challenge of the teaching } \\
\text { position }\end{array}$ & 113 & 0 & 4 & 1.752 & 1.122 \\
\hline $\begin{array}{l}\text { Satisfaction with salary and } \\
\text { benefits }\end{array}$ & 113 & 0 & 4 & 1.735 & 1.303 \\
\hline $\begin{array}{l}\text { Spouse/partner's } \\
\text { employment }\end{array}$ & 111 & 0 & 4 & .982 & 1.408 \\
\hline $\begin{array}{l}\text { Materials and resources } \\
\text { available }\end{array}$ & 113 & 0 & 4 & .903 & 1.134 \\
\hline $\begin{array}{l}\text { Opportunity to practice } \\
\text { multiage teaching }\end{array}$ & 113 & 0 & 4 & .867 & 1.138 \\
\hline $\begin{array}{l}\text { Access to recreational } \\
\text { activities }\end{array}$ & 110 & 0 & 4 & .391 & .847 \\
\hline School's recruiting program & 111 & 0 & 4 & .198 & .672 \\
\hline
\end{tabular}

When the 12 recruitment factors were grouped into the Boylan et al. (1993) four spheres of influence, the family/personal sphere and whole school spheres were most influential to teacher recruitment. An ANOVA test was administered to compare the means of the four spheres influencing teacher recruitment to test the null hypothesis. The $F$ test value of 5.644 was large enough to reject the null hypothesis indicating differences between the mean scores of the four spheres for teacher recruitment were larger than what could be expected by chance alone. A post hoc pairwise comparison with Bonferroni adjustment found a statistical difference between the whole school sphere and the community sphere as well as between the whole school and classroom spheres. Thus, the study did find a statistical difference between the importance of the recruitment factors influencing teachers to accept rural teaching assignments. While the family/personal sphere was most influential according to the descriptive data, it was not found to be statistically significantly higher than the other spheres. However, the second most influential sphere according to the descriptive data, the whole school sphere, was found to have a higher statistical significance difference than the other spheres. Both the family/personal and the whole school spheres were very influential in the decision for teachers to accept rural teaching assignments.

\section{Research Question Two Results}

Teachers were asked what retention factors most influenced their decision to remain teaching in the smallest Illinois public school districts.

"Relationships with students," "safe environment," "small class size," and "support from administrator" were the retention factors with the highest means that influenced teachers to remain teaching in rural schools. When the 16 retention factors were grouped by the Boylan et al. (1993) four spheres of influence, the community and the within classroom spheres were most influential to teacher retention. Table 3 includes the means and standard deviation for each of the 16 recruitment factors as well as the number of teacher respondents who chose to rate each factor.

Table 3

Influential Retention Factors

\begin{tabular}{|c|c|c|c|c|c|}
\hline Retention Factors & $\mathrm{N}$ & Min & Max & $\mathrm{M}$ & SD \\
\hline Relationships with students & $1 \overline{12}$ & 1 & 4 & $3 . \overline{25} 9$ &.$\overline{836}$ \\
\hline Safe environment & 112 & 0 & 4 & 2.920 & 1.050 \\
\hline Small class size & 112 & 0 & 4 & 2.705 & 1.152 \\
\hline Support from administrator & 112 & 0 & 4 & 2.696 & 1.130 \\
\hline $\begin{array}{l}\text { Family and home is close } \\
\text { by }\end{array}$ & 109 & 0 & 4 & 2.661 & 1.375 \\
\hline Rural lifestyle & 111 & 0 & 4 & 2.577 & 1.325 \\
\hline $\begin{array}{l}\text { Support from parents and } \\
\text { community }\end{array}$ & 112 & 0 & 4 & 2.545 & 1.146 \\
\hline School facility & 112 & 0 & 4 & 2.250 & 1.159 \\
\hline $\begin{array}{l}\text { Recognition for job well } \\
\text { done }\end{array}$ & 112 & 0 & 4 & 2.045 & 1.196 \\
\hline $\begin{array}{l}\text { Challenge of the teaching } \\
\text { position }\end{array}$ & 112 & 0 & 4 & 1.884 & 1.145 \\
\hline
\end{tabular}




\begin{tabular}{lccccc}
$\begin{array}{l}\text { Satisfaction with salary and } \\
\text { benefits }\end{array}$ & 112 & 0 & 4 & 1.804 & 1.223 \\
$\begin{array}{l}\text { Materials and resources } \\
\text { available }\end{array}$ & 112 & 0 & 4 & 1.795 & 1.267 \\
$\begin{array}{l}\text { Professional development } \\
\text { opportunities }\end{array}$ & 112 & 0 & 4 & 1.679 & 1.117 \\
$\begin{array}{l}\text { Desire to keep tenure status } \\
\begin{array}{l}\text { No offer to find a teaching } \\
\text { assignment in a higher }\end{array}\end{array}$ & 112 & 0 & 4 & 1.625 & 1.537 \\
$\begin{array}{l}\text { paying district } \\
\text { Spouse/partner employment }\end{array}$ & 110 & 0 & 4 & 1.333 & 1.516 \\
\hline
\end{tabular}

Once again an ANOVA test was administered to compare the mean scores of the four spheres and to test the null hypothesis. The $F$ value of 32.02 was even higher for teacher retention than it was for teacher recruitment once again enabling the null hypothesis to be rejected (there was a difference between the retention factors that influenced teacher decisions to remain teaching in the smallest school districts in Illinois). A post hoc pairwise comparison with Bonferroni adjustment revealed statistical differences between the community and whole school spheres, the community and family/personal spheres and between the community and within classroom spheres. Thus, the study did find a statistical difference between the importance of the retention factors influencing teachers to remain teaching in their rural schools with the community and within classroom spheres most influential in the decision of rural teachers to remain teaching in their rural school districts.

\section{Research Question Three Results}

The study also examined what perceived strategies would rural teachers suggest to improve teacher recruitment and increase teacher retention in the smallest Illinois public school districts. Four of the strategies were chosen by over $50 \%$ of the respondents: "provide competitive insurance packages," "salaries competitive with other states," "more flexibility with scheduling, including flexible personal days," and "state funded $\$ 1000$ salary increase for all teachers working in small, rural public school districts." Table 4 displays the results of the recruitment and retention strategies ranked in descending order.

\section{Table 4}

Most Effective Recruitment and Retention Factors as Perceived by Rural Teachers

Strategies

Provide competitive insurance packages

Salaries competitive with other states

More flexibility with scheduling including flexible personal days

State funded $\$ 1000$ salary increase for all teachers working in small, rural public school districts

Financial assistance for advanced college or additional endorsements

State sponsored loan forgiveness program for teachers who accept jobs in high demand/low supply areas - up to $\$ 3,000$ per year for up to four years High quality professional development opportunities and opportunities to travel for professional growth

Whenever possible, hire teachers who live locally

Mentoring and support programs for new teachers

Help new teachers with student loan debt

Marketing of whatever the district has to offer - location, recreation, cost of living, safe and healthy environment

Student teacher placement

Stipend for teachers who earn National Board Certification and continue teaching in the state

Grow Your Own teacher programs helping local people receive teacher certification in exchange for commitment to teach in local small school

\begin{tabular}{|c|c|}
\hline$\underline{N}$ & Percentage \\
\hline & Response \\
\hline 62 & $59.05 \%$ \\
\hline 61 & $58.10 \%$ \\
\hline 58 & $55.24 \%$ \\
\hline 55 & $52.38 \%$ \\
\hline 44 & $41.90 \%$ \\
\hline 36 & $34.29 \%$ \\
\hline 35 & $33.33 \%$ \\
\hline 35 & $33.33 \%$ \\
\hline 34 & $32.38 \%$ \\
\hline 32 & $30.48 \%$ \\
\hline 22 & $20.95 \%$ \\
\hline 12 & $11.43 \%$ \\
\hline 10 & $9.52 \%$ \\
\hline 5 & $4.76 \%$ \\
\hline
\end{tabular}


districts

Help with finding housing or help with low interest loans to buy houses $\quad 4 \quad 3.81 \%$

\section{Discussion}

The results of the present Illinois study were compared and contrasted to the earlier Davis (2002) study. Both the present Illinois study and the Davis study found the family/personal sphere to have the highest mean score influencing teachers' decisions to accept rural teaching assignments. However, the whole school sphere was more influential to teacher recruitment in the present study than it was found to be in the Davis study. For teacher retention, both the present Illinois study and the Davis study found the community and within classroom spheres to be most influential. These findings supporting the importance of the community sphere support the earlier findings of Boylan (1993) in his study of 1100 rural

Australian teachers.

Rural teacher satisfaction was also examined in both the present Illinois study and the Davis study using the responses teachers provided to the survey's three teacher satisfaction questions which originally appeared in the School and Staffing Survey from the National Center for Education Statistics. The Illinois teacher respondents indicated they planned to remain teaching for the foreseeable future $(83.9 \%)$ at higher percentage levels than the NCES 2011-12 national average (73.5\%) and the prior Davis (2002) study of Montana teachers $(73.1 \%)$. The Illinois teacher respondents indicated they would choose teaching as a career all over again $(67.6 \%)$ at nearly the same percentage levels as the NCES 2011-12 national average $(66.6 \%)$ and slightly lower than the Davis study $(70 \%)$. The findings from the satisfaction questions suggest 1) the rural Illinois teachers in the study were happy with their assignments and 2) the high levels of teacher turnover that rural schools experience are not a result of disillusionment with the profession.

Rural educational leaders will want to consider the following recommendations based on the study's findings to improve the recruitment of highly qualified teachers and increase teacher retention in their specific buildings and districts.

\section{Implications for Practitioners}

\section{Recruit Teachers with Rural Backgrounds}

Rural educational leaders should place particular weight on whether teacher applicants have a rural background. Teachers with a rural background are more apt to understand rural communities, which is important since the community itself is the most influential sphere to determining whether a teacher will remain teaching in the same rural school or district. Rural educational leaders should be sure to include questions in the interview process about rural living.

\section{Recruitment Factors Differ from Retention Factors}

Rural educational leaders need to recognize the spheres of influence that determine whether a teacher will accept a rural teaching assignment are not the same influence spheres that determine whether a teacher will remain in their rural teaching assignment. While the family/personal and whole school spheres are most important to attracting rural teachers, they are not the spheres that most influence their decision to remain teaching in rural districts. The community and within classroom spheres are the spheres that most influence rural teachers to remain teaching in the same rural schools and districts.

\section{Reduce Social and Geographic Isolation}

Since most rural teachers accept rural teaching assignments because it is their only job offer, or because the rural lifestyle appeals to them, rural communities need to make every effort to include teacher transplants into the social fabric of the community lessening the isolation many rural teachers experience. Social and geographic isolation have both been identified as major obstacles to teacher recruitment and retention in rural schools (McClure \& Reeves, 2004; Zhang, 2008). To lessen social and geographic isolation, rural leaders need to take action to develop a stronger community connection with rural teachers, most of whom in this study did not live in the communities where they taught. Rural communities are often busy places with community pot lucks, book clubs, softball games, dances, and card nights. Community members should make sure their teachers are invited to these functions and made to feel welcome. Parents and community members should make an effort to get to know their rural teachers as friends and neighbors, more than just their child's teacher.

\section{Develop Effective Marketing Programs}

Since the survey results showed the rural teachers who participated in this study did not consider their district's marketing efforts to be effective, rural educational leaders will want to 
implement best practices for recruitment marketing and revamp their programs. If there are not recruitment marketing programs in place, then rural educational leaders will want to put them in place. To best meet the needs of rural school districts, recruitment marketing programs should be strategic, specific for hard to fill areas, sustainable, and community rooted (Ahearn, Harmon, and Sanders, 2005; McClure and Reeves, 2004).

\section{Decrease Emphasis on Homegrown Teachers}

The importance of homegrown teachers and housing programs for rural schools may be overstated by rural research. Current rural teachers in the smallest school districts of Illinois mostly lived outside of the rural districts they taught in and, as a result, were not very interested in either program. Both the Davis (2002) Montana study and the present Illinois study demonstrated the strong influence community factors play on teacher retention. The findings of the present study suggest that rural leaders may want to focus more on increasing teacher retention by integrating their present teachers into the community rather than developing homegrown recruitment programs.

\section{Provide Exit Interviews when Rural Teachers Quit}

Rural teachers are highly satisfied with the teaching profession even though they have higher turnover than teachers in more urban settings. This suggests rural teachers are leaving their school districts for reasons other than dissatisfaction with their teaching position. Rural educational leaders should conduct exit interviews whenever possible with their teachers to better understand why they are leaving. Exit interviews will provide rural educational leaders with the additional information they need to understand the factors leading to higher than average teacher turnover and the opportunity to improve teacher retention.

\section{Future Research Recommendations}

\section{Replicate the Study in Other States, Larger Rural Schools}

The most influential spheres of influence for teacher recruitment and retention in the present study mirrored the findings of the Davis (2002) study in Montana. The present study should be replicated to determine if its findings can be generalized to other states and larger rural school districts as well.
Investigate Small Rural School Districts that have used the Boylan (1993) Four Spheres of Influence to Increase Teacher Recruitment and Retention

An interesting follow up to the present study would be a study of small rural school districts who have used the Boylan (1993) four spheres of influence to increase teacher recruitment and retention in their school districts.

\section{Improve upon Survey Instrument Recruitment Factors}

The Davis (2002) survey instrument could be improved upon. While the 28 recruitment and retention factors had a high internal consistency reliability coefficient when tested together (.808), the 12 recruitment factors had a weaker internal consistency reliability coefficient (.575). Therefore the recruitment factors in particular could be improved upon.

\section{Research Survey Participation Modes}

The researcher was particularly intrigued by the participation rates garnered from the mixed-mode method of survey collection. The quantitative study had a strong participation rate of $54 \%$ with 113 of the 210 potential participants responding. However, 94 of the teacher participants or $83 \%$ of participants responded to either the first paper mailing (78) or the second paper mailing (16). Only 19 teachers chose to participate in the study electronically. The strong participation rate for the paper mailing calls into question the popularity of electronic survey instruments. More research should be conducted on whether paper surveys garner a stronger response than electronic surveys and with which populations. While electronic surveys are more cost effective and offer ease of collection for the researcher, if paper surveys deliver better participation results then future educational researchers will want to continue to include them in their survey collection methods.

\section{Research how to attract more diverse teachers}

Educational researchers need to explore how to attract non-white teachers to rural school districts when these school districts are located in mostly white populated areas. While the enrollment of Illinois rural schools is just $15 \%$ minority (Strange et al., 2012), diverse role models are important even for homogenous students who will grow up to work with people of all ethnicities. The results of the present study suggest just how challenging recruitment of ethnically diverse teachers is in rural school districts 
when family/personal reasons strongly influence teacher recruitment and connection to the community impacts teacher retention.

\section{Concluding Statement}

This research study identified teacher recruitment and retention factors in the 24 smallest Illinois public school districts with enrollments of less than 100 students. A major finding in the study was that the spheres of influence that most attract teachers to accept rural teaching assignments (family/personal and whole school) were not the same spheres of influence that most determined whether the same teachers remained teaching in their rural schools (community and within classroom). This finding suggested that rural communities and rural schools can play a critical role in increasing teacher retention by providing more support to rural teachers and involving them in their communities.

This study replicated the Davis (2002) study of rural teacher recruitment and retention and, as with the earlier study, found the most influential Boylan et al. (1993) sphere of influence for teacher recruitment to be family/personal. Most teachers accepted rural teaching assignments because it was their only job offer and rural living appealed to them. However, rural teachers were most influenced to remain in their teaching assignments because of the community sphere's influence, which also mirrored the Davis findings.

As with the Davis (2002) Montana study a decade ago, the Illinois rural teachers in this study reported high levels of teacher satisfaction with the vast majority planning to remain in the teaching profession and indicating they would choose teaching as a career all over again. These findings suggest that rural Illinois teachers were happy with their teaching assignments. Therefore, high levels of rural teacher turnover were not a result of disillusionment with the profession.

Research has shown the lasting power of rural school districts in the education of the nation's young people. The continued prevalence of rural districts demonstrates that rural schools are not going anywhere. Rural school leaders can make sure their rural teachers reflect the staying power of their districts by enacting the findings of the present study. By recognizing what attracts teachers to teach in rural schools is not necessarily what motivates them to stay, rural leaders should be able to increase retention of their teachers by facilitating more community support for them.

\section{References}

Ahearn, C., Harmon, H., Sanders, J. (2005). How to recruit and retain teachers and other school leaders in hard-to-staff rural and small school districts. Greensboro, NC: Regional Educational Laboratory Southeast. http://www.serve.org/FileLibraryDetails.aspx?i $\mathrm{d}=76$.

Bogler, R. (2002). Two profiles of schoolteachers: A discriminant analysis of job satisfaction.

Teaching and Teacher Education, 18, 665-673. Retrieved from http://www.stat.ufl.edu/STA\%204702/Spring\% 2007/DA\%20Bogler\%20schoolteacher\%20job $\% 20$ satisfaction \%202002.pdf

Boylan, C., Sinclair, R., Smith, A, Squires, D., Edwards, J., Jacob, A., O’Malley, D., \& Nolan, B. (1993). Retaining teachers in rural schools: Satisfaction, commitment, and lifestyle. Retrieved from http://files.eric.ed.gov/fulltext/ED365499.pdf

Davis, M. (2002). An investigation of factors related to teacher retention in small rural school districts in Montana (Doctoral dissertation). Retrieved from http://scholarworks.montana.edu/xmlui/bitstrea $\mathrm{m} /$ handle/1/8187/31762103589360.pdf?sequenc $\mathrm{e}=1$ \&isAllowed $=\mathrm{y}$

Dee, T. S. (2004). Teachers, race, and student achievement in a randomized experiment. The Review of Economics and Statistics, 86(1), 195210.

Dee, T. S. (2007). Teachers and the gender gaps in student achievement. The Journal of Human Resources, 42(3), 528-554.

Dessoff, A. (2010, June). Persuading teachers to go rural: District administrators craft incentives to attract and retain teachers. District Administration, 46(6), 58-60. Retrieved from: http://www.districtadministration.com/article/pe rsuading-teachers-go-rural

Eberhard, J., Reinhardt-Mondragon, P., \& Stottlemyer, B. (2000). Strategies for new teacher retention: Creating a climate of authentic professional development for teachers with three or less years of experience. Corpus Christi: TX: A\&M University, South Texas Research and Development Center. Retrieved from http://eric.ed.gov/?q=Strategies+for+New+Teac her+Retention\%3a+Creating $+\mathrm{a}+\mathrm{Climate}+\mathrm{of}+\mathrm{A}$ uthentic+Professional+Development+for+Teac 
hers+with+Three+or+Less+Years+of+Experien ce\&id=ED450116

Huling, L. (1998, November). Texas board for educator certification panel on novice teacher induction support system: Final report. Austin, TX: Texas State Board for Educator Certification.

Huysman, J. (2008). Rural teacher satisfaction: An analysis of beliefs and attitudes of rural teachers' job satisfaction. Rural Educator, 29(2), 31-38. Retrieved from http://www.ruraleducator.net/archive/29-2/292_Huysman.pdf

Ingersoll, R. (2001). Teacher turnover and teacher shortages: An organizational analysis. American Education Research Journal, 38(3), 499-534. Retrieved from http://files.eric.ed.gov/fulltext/ED526355.pdf

Jimerson, L. (March 2003). The competitive disadvantage: Teacher compensation in rural America. Washington, DC: The Rural School and Community Trust Policy Brief. Retrieved from http://files.eric.ed.gov/fulltext/ED474248.pdf

Kalmar, B., \& Ruby, H. (1930). Hello, I must be going. (Recorded by Groucho Marx). On An Evening with Groucho [LP record]. Santa Monica, California: A \& M Records. (1972).

Maakel, M., \& Plucker, J. (2014). Facts are more important than novelty: Replication in the education sciences. Educational Researcher, 43 (6), 304-316.

Maranto, R., \& Shuls, J. V. (2012). How do we get them on the farm? Efforts to improve rural teacher recruitment and retention in Arkansas. Rural Educator, 34(1). Retrieved from http://www.eric.ed.gov.ezproxy.wiu.edu/conten tdelivery/servlet/ERICServlet?accno=EJ100010 1

McClure, C., Reeves, C., \& AEL, I. V. (2004). Rural teacher recruitment and retention review of the research and practice literature. AEL, Inc.

Retrieved from

http://www.eric.ed.gov.ezproxy.wiu.edu/conten tdelivery/servlet/ERICServlet?acno=ED484967

National Center for Education Statistics. (2013). Number of public elementary and secondary education agencies, by type of agency and state or jurisdiction: 2010-11 and 2011-12. U.S. Department of Education. Retrieved from http://nces.ed.gov/programs/digest/d13/tables/dt 13_214.30.asp

National Commission on Teaching and America's Future. (2007). The high cost of teacher turnover. Retrieved from http://www.nctaf.org/wpcontent/uploads/2012/01/NCTAF-Cost-of Teacher-Turnover-2007-policy-brief.pdf

Natkin, J., \& Mooney, K. (2003). Preliminary report on nominal and focus group sessions. The SERVE Center at the University of North Carolina at Greensboro.

Rice, J., \& Urban Institute, N. (2010). The impact of teacher experience: Examining the evidence and policy implications. Brief No. 11. National Center for Analysis of Longitudinal Data in Education Research. Retrieved from http://www.caldercenter.org/publications/uploa d/1001455-impact-teacher-experience.pdf

Riggs, L. (2013, October 18). Why do teachers quit and why do they stay? The Atlantic Monthly 312(3). Retrieved from http://www.theatlantic.com/education/archive/2 013/10/why-do-teachers-quit/280699/

Southeast Center for Teaching Quality. (2004). Unfilled promise: Ensuring high quality teachers for our nation's students. No Child Left Behind: A status report from southeastern schools. Chapel Hill, NC: Southeast Center for Teaching Quality. Retrieved from www.teachingquality.org

Strange, M., Johnson, J., Showalter, D., \& Klein, R. (2012). Why Rural Matters 2011-12: The Condition of Rural Education in the 50 States. A Report of the Rural School and Community Trust Policy Program. Washington, DC: Rural School And Community Trust. Retrieved from http://files.eric.ed.gov/fulltext/ED528634.pdf

Williams, M. (1960). Stay (Recorded by Jackson Browne). On Running on empty (CD). Los Angeles, CA: Elektra/Rhino. (Reissued 2005).

U.S. Census Bureau. (1995). 1990 Urban and rural definitions. Retrieved from http://www.census.gov/geo/reference/docs/ua/u rdef.txt.

U.S. Department of Education. (2012). New data from U.S. Department of Education highlights educational inequities around teacher experience, discipline and high school rigor. Retrieved from: http://www.ed.gov/news/pressreleases/new-data-us-department-educationhighlights-educational-inequities-aroundteachers

Zhang, Y. (2008). Some perspectives from rural school districts on the No Child Left Behind Act. Washington, DC: Center on Education Policy. Retrieved from http://files.eric.ed.gov/fulltext/ED503795.pdf 


\section{About the author:}

Dr. Ulferts is a veteran educator with 25 years of administrative and teaching experience both in rural and in urban school districts. He is currently Superintendent-Principal of the Shirland School District \#134 in Shirland, Illinois, a small K-8 rural district, and is an Adjunct Professor for Concordia University Wisconsin. 